\title{
Pengembangan Bahan Ajar (Modul) Biologi pada Materi Ekosistem di Kelas X SMA Negeri 1 Wawonii Tengah
}

\author{
Muragmi Gazaly ${ }^{1)}$; Yayan Sapitri' ${ }^{2)}$; Hasrin Lamote ${ }^{3)}$ \\ 1) Dosen Tadris Biologi, Fakultas Tarbiyah dan Ilmu Keguruan (FTIK), Institut Agama Islam Negeri (IAIN) \\ Kendari; \\ 2) Alumni Tadris Biologi, FTIK, IAIN Kendari \\ 3) Dosen Tadris Matematika, FTIK, IAIN Kendari \\ Email Korespondensi: muragmi@yahoo.co.uk
}

\begin{abstract}
The purpose of writing this article is to assess the feasibility of biology teaching materials (learning modules) on Eco-system material. This research is a development research which refers to the 4-D Thiagarajan Model (define, design, develop, and disseminate), namely the stages defining, designing, developing and distributing. The research analysis was carried out in three stages, namely the defining, designing and development stages. The data used came from the results of research on the identification of mangrove species on the Lamongupa beach and the biology learning module. The appropriateness of the material in teaching materials (learning modules) is evaluated on three aspects, namely the characteristics, quality and usability of the modules and at the same time this research also ensures the feasibility of the modules that have been developed. The findings of this study indicate that the learning module developed used in SMA Negeri 1 Wawonii Tengah is feasible based on the results of validation by subject matter experts, lecturers and teachers with a percentage of $81 \%$ and the results of field trials on students that are $80 \%$ with the category of learning modules very feasible to use.
\end{abstract}

Keywords: Feasibility of the learning module, Ecosystem

\begin{abstract}
Abstrak
Tujuan penulisanartikel ini adalah untuk menilai kelayakan bahan ajar (modul pembelajaran) biologi pada materi Ekositem. Penelitian ini adalah penelitian pengembangan yang mengacu pada model 4-D Thiagarajan (define, design, develop, dan disseminate) yakni tahap pendefinisian, perancangan, pengembangan dan penyebaran. Analisis riset ini dilakukan pada tiga tahap yaitutahap pendefinisian, perancangan dan pengembangan. Data yang digunakan bersumberdari hasil riset tentang identifikasi jenis mangrove di pantai Lamongupa dan modul pembelajaran biologi. Kelayakan materi pada bahan ajar (modul pembelajaran) dievaluasi pada tiga aspek yaitu karakteristik, kualitas dan kegunaan modul serta pada saat yang sama riset ini juga memastikan kelayakan modul yang telah dikembangkan. Temuan penelitian ini menunjukkan bahwa modul pembelajaran yang dikembangkan yang digunakan di SMA Negeri 1 Wawonii Tengah layak digunakanberdasarkan hasil validasi oleh para ahli materi dosen dan guru dengan presentase $81 \%$ dan hasil uji coba lapangan pada siswa yakni $80 \%$ dengan kategori modul pembelajaran sangat layak digunakan.
\end{abstract}

Kata kunci: Kelayakan modul pembelajaran, Ekosistem

\section{PENDAHULUAN}

Salah satu faktor pendukung terhadap keberhasilan penerapan kurikulum 2013 yang berlaku saat ini adalah ketersediaan perangkat pembelajaran yang layak dan relevan. Perangkat pembelajaran mencakup rencana proses pembelajaran, penilaian, media dan metode yang akan digunakan dalam pembelajaran. Pada proses pembelajaran, para tenaga pendidik harus menyesuaikan segala kegiatan pembelajarannya dengan Kurikulum tersebut, khususnya dalam penyusunan perangkat pembelajaran yang merupakan salah satu alat penunjang keberhasilan pembelajaran. Sesuai dengan Permendiknas Nomor 56 Tahun 2013 tentang standar proses, yang antara lain mengatur tentang perencanan proses pembelajaran menegaskan bahwa pendidik pada satuan pendidikan harus mampu mengembangkan perencanaan pembelajaran (Muqodas et al., 2015).

Proses belajar mengajar dapat terlaksana dengan efektif dan berhasil dengan baik jika ada keterlibatan komponen dalam proses belajar yaitu kurikulum, guru, siswa, metode pembelajaran, sumber belajar, media, dan evaluasi yang konsisten. Salah satu faktor dalam proses belajar mengajar adalah sumber belajar, seperti bahan ajar (Nurrita, 2018). Bahan ajar dapat digunakan untuk menilai pencapaian hasil belajar siswa. Salah salah satu komponen pengajaran yang dapat digunakan adalah modul. Modul ini adalah materi pengajaran tertulis yang memungkinkan siswa belajar secara mandiri serta dapat dipelajari di mana saja tanpa harus didampingi oleh guru dalam proses belajarnya. Penggunaan modul juga dapat membantu siswa secara efektif memahami materi pelajaran serta dapat menunjang keberhasilan hasil belajar (Rakhmatullah et al., 2020). 
Berdasarkan observasi awal dilakukan peneliti melalui wawancara dengan guru-guru biologi kelas X SMA Negeri 1 Wowonii Tengah mengungkapkan masih rendahnya daya serap siswa dalam memahami materi biologi khususnya materi ekosistem. Hal tersebut dikarenakan siswa terbiasa dan masih tergantung pada informasi dari guru, penjelasan verbal ditambah dukungan bahan-bahan ajar yang diberikan oleh guru. Namun para siswa masih kesulitan memahami bahan-bahan ajar yang ada. Bahan-bahan ajar yang tersedia dalam bentuk buku paket atau pegangan siswa dimana penyajian materinya belum memenuhi karakteristik materi pembelajaran biologi yang menuntut banyak menggunakan visualisasi konsep untuk menjelaskan materi-materi biologi yang abstrak. Khusus materi ekosistem memerlukan penyajian visual disamping penjelasan verbal untuk mempermudah pemahaman siswa terhadap konsep ekosistem karena materi ekosistem banyak menjelaskan fenomena lingkungan alam yang tidak semua bisa dilihat dengan kasat mata. Penyajaian dalam bentuk verbal akan menyulitkan siswa dalam mengidentifikasi dan mengembangkan pemahaman mereka terhadap materi ekosistem. Oleh karena itu, dibutuhkan tersedianya bahan ajar berupa modul pembelajaran yang dapat membantu siswa secara mandiri mampu mengeksplorasi materi sehingga mereka dapat memahami materi pembelajaran ekosistem sesuai tujuan pembelaharan dan hasil belajar yang diharapkan.

Untuk itulah maka guru sebagai pendidik profesional diharapkan memiliki kemampuan mengembangkan bahan ajar sesuai dengan mekanisme yang ada dengan memperhatikan karakteristik dan lingkungan sosial peserta didik. Salah satu upaya dalam meningkatkan pemahaman materi ekosistem adalah penggunaan bahan ajar agar menjadi lebih menarik, karena contoh-contoh yang diambil sangat dekat dengan kehidupan peserta didik dan bersifat kontekstual. Salah satu cara alternatif yang dapat dilakukan oleh guru dalam mengajar pada materi ekosistem tanpa melakukan fiel trip adalah menggunakan atau mengembangkan bahan ajar yang berkaitan dengan lingkungan yang dekat dengan siswa. Peran bahan ajar dalam membantu guru biologi harus dimaksimalkan dalam proses pembelajaran. Bahan ajar diharapkan dapat berperan dalam mengungkap dan memberikan fakta-fakta yang ada di hutan mangrove sebagai salah satu usaha penanggulangan masalah yang terjadi pada hutan mangrove melalui media komunikasi dalam proses belajar mengajar di sekolah (Haerullah, 2017).

Lingkungan atau alam sekitar memiliki peran yang begitu penting dalam kegiatan pembelajaran khusunya pada mata pelajaran biologi. Dalam upaya meningkatkan efektivitas suatu pembelajaran seorang guru dituntut agar mampu menggunakan bahan ajar yang isi materinya lebih terperinci dan sesuai dengan kompetensi dalam hal ini pengembangan berupa hanout) (Setiawan \& Mustangin, 2020). Salah satu upaya dalam meningkatkan pemahaman konsep pada materi keanekaragaman hayati adalah dengan mengembangkan bahan ajar yang menyajikan pengidentifikasian struktur morfologi tumbuhan mangrove yang dapat dijadikan sebagai dasar pengelompokan keragaman tumbuhan mangrove (Lorena et al., 2019).

Oleh karena itu, peneliti mencoba merancang perangkat pembelajaran berupa modul pembelajaran yang mengaplikasikan visual komunikasi untuk memperjelas konsep-konsep dasar ekosistem agar tidak terjadi kesalahan dalam memahami materi ekosistem. Sebagaimana dikemukakan oleh Lufri bahwa materi pembelajaran biologi syarat denganobjek yang divisualisasikan dan syaratdengan konsep yang mempunyai sifat yang hirarki (Wahyuni \& Lufri, 2021).

Peneliti memulai langkah awal di SMA Negeri 1 Wawonii Tengah dengan mengenalkan modul pembelajaran biologi yang disusun melalui serangkaian kegiatan penelitian yang dilakukan dengan menyusun modul Ekosistem. Pembelajaran biologi dengan menggunakan modul berbasis riset akan lebih membuat siswa tertarik dan antusias terhadap pembelajaran. Tujuan dari penelitian ini adalah untuk mengetahui kelayakan bahan ajar (modul pembelajaran) biologi berbasis riset tema Ekosistem. Selain itu tujuan lain adanya pembelajaran biologi menggunakan modul berbasis riset tidak hanya untuk memberi materi saja, tetapi juga menyediakan wadah yang dapat membimbing siswa dalam menemukan dan membangun pengetahuan mereka sendiri.

Penggunaan modul penelitian dalam proses belajar biologi diharapkan siswa lebih tertarik dan antusias belajar. Tujuan penelitian ini adalah untuk menilai kelayakan dan kegunaan modul biologi pada topik ekosistem. Selain itu, penelitian ini diharapkan dapat meningkatkan pemahaman materi biologi menggunakan modul berbasis riset penelitian, karena modul ini tidak hanya untuk menyediakan konten, tetapi juga untuk menyediakan ruang belajar bagi siswa untuk menemukan dan mengembangkan pengetahuan mereka sendiri. Modul berbasis riset yang dikembangkan memiliki gambar menarik yang dapat menumbuhkan karakter dan kecintaan siswa terhadap suatu ekosistem (Lestari et al., 2019).

\section{METODE PENELITIAN}

Metode yang digunakan dalam penelitian ini adalah metode pengembangan (Research and Development) dengan model 4-D (define, design, develop, dan desiminasi), yang dilaksanakan di SMA Negeri 1 Wawonii Tengah di kelas X pelajaran Biologi materi Ekosistem, dari bulan Desember 2019 sampai Maret 2020. Tahapan pelaksanaannya adalah:

1. Tahap Define

Pada tahapan ini peneliti melakukan analisis kurikulum K13, merumuskan indikator, analisis karakteristik 
siswa dan analisis konsep.

2. Tahap Design

Tahap perancangan ini, peneliti memilih format yang sesuai dengan format penulisan Bahan Ajar yang baik dan benar dengan memperhatikan standar mutu buku pelajaran IPA SMA yang ditentukan pusat perbukuan dari Depdik- nas 2007, dan panduan pengembangan bahan ajar dari Depdiknas 2008 yang meliputi: aspek materi, aspek penyajian, aspek bahasa dan keterbacaan.

3. Tahap Develop

Tahap pengembangan ini dilakukan validasi isi dan konstruk bahan ajar. Validatornya adalah oleh pakar pendidikan biologi, guru-guru biologi Kelas X SMA Negeri 1 Wawonii Tengah k. Hasil validasi menjadi masukan untuk merevisi dan memperbaiki bahan ajar.

4. Tahap disseminate

Tahap ini merupakan tahap penyebaran (desiminasi) bahan ajar yang dihasilkan. Pada penelitian ini tahap disseminate tidak dilakukan mengingat keterbatasan waktu dan biaya yang dimiliki. Diharapkan dan diupayakan untuk dilanjutkan ke tahap ini untuk melengkapi hasil penelitian ini.

Sumber data yang digunakan bersumber dari data hasil penelitian identifikasi jenis mangrove di pantai Lamongupa dan silabus pembelajaran biologi. Teknik pengumpulan datanya menggunakan beberapa jenis data yaitu diantaranya 1). Uji coba awal(validasi para ahli), 2). Uji coba lapangan (mengukur kelayakan modul). Dalam penelitian ini menggunakananalisis deskriptif.

1. Kelayakan Modul

Menghitung kelayakan modul pembelajaran dapat menggunakan perhitungan persentase, dengan menggunakan rumus berikut ini:

Presentasi kelayakan $(\%)=\frac{\text { Skoryangdiobservasi }}{\text { Skoryangdiharapkan }} \times 100 \%$.

Penghitungan persentase digunakan untuk mengetahui interpretasi yang diukur, dengan menggunakan kriteria kelayakan sebagai berikut:

Tabel 1. Skala Persentase

\begin{tabular}{ccc}
\hline Persentase pencapaian & Skala nilai & Interpretasi \\
\hline $76-100 \%$ & 4 & Sangat Baik \\
$56-75 \%$ & 3 & Baik \\
$40-55 \%$ & 2 & Cukup \\
$0-39 \%$ & 1 & Kurangbaik
\end{tabular}

(Suharsimi, 2006)

\section{HASIL PENELITIAN}

Penelitian kelayakan bahan ajar (modul pemebelajaran) ekosistem dilaksanakan dengan menggunakan model pengembangan 4-D (define, design, develop, dan disseminate), karena keterbatasan peneliti maka hanya sampai pada tahap pengembangan (develop). Tahap pendefinisian (define) adalah tahap pertama dalam pengembangan modul ini, ada lima langkah dalam tahap ini yang terdiri dari analisis kurikulum, karakteristik siswa, penyelesaian tugas, konsep materi, dan tujuan pembelajaran. Pada tahapan ini diketahui bahwa 1)daya serap dan ketercapaian hasil belajar belum memenuhi ketuntasan belajar minimal. 2) Peserta didik/Siswa Kelas XI SMAN Wawonii Tengah sulit memahami materi ekosistem. 3) analisis tugas, keterampilan, dan indikator perlu penyesuaian untuk penyusunan bahan ajar (Anafiyah et al., 2015).

Tahap kedua yaitu perancangan (design) bertujuan untuk merancang perangkat pembelajaran berupa modul penelitian dengan sub materi ekosistem. Perancangan modul penelitian ini meliputi dua langkah yaitu pertama pemilihan format seperti pemilihan sampul modul, dan yang kedua desain modul berisi pemilihan jenis tulisan, tata letak gambar dalam modul, grafik dan pemetaan materi dalam modul. Pada tahapan ini peneliti telah merancang modul pembelajaran pada materi ekosistem yang meliputi isi, struktur materinya, dan disain layout modul.

Tahap selanjutnya dalam pembuatan modul peneltian ini yaitu tahap pengembangan (develop), tahap ini bertujuan untuk melihat kelayakan modul penelitian sebagai buku pendamping siswa pada proses pembelajaran. Untuk mengetahui kelayakan modul maka dilakukan uji validasi oleh ahli materi dan ahli media serta dilakukan penilaian respon siswa terhadap modul pembelajaran.

Berdasarkan tahapan-tahapan di atas diperoleh masukan untuk memperbaiki dan mengembangkan modul penelitian ini. Masukan tersebut antara lain: 1). Isi: materi berkaitan dengan ekositem pemilihan gambar terhadap materi masih kurang sesuai, pembuatan soal latihan diperjelas agar mudah dipahami oleh siswa 2). Bahasa dan gambar: Penggunaan istilah, dan kesalahan dalam penulisan masih kurang kesalahan dalam pengetikan, penggunaan KKO kurang sesuai degan tujuan yang ingin di capai. 
Berdasarkan masukan tersebut maka dilakukan perbaikan antara lain: 1) isi: materi dilengkapi dengan gambar-gambar sesuai materi yang ditampilkan, soal perjelas sesuai tujuan yang ingin dicapai. 2). Bahasa dan gambar: penggunaan istilah, dan penulisan KKO telah disesuaikan dan diperbaiki begitupun kesalahan dalam pengetikan.

Kelayakan modul penelitian iniyang dibuat/dikembangkan dapat diketahui dari hasil validasi dari beberapa ahli yakni dari dosen dan juga guru. Hasil validasi berupa data kuantitatif yang digunakan sebagai dasar untuk menentukan kualitas atau kelayakan buku.

Tabel 2. Hasil Penilaian Validasi kelayakan bahan ajar (modul pembelajaran) Materi Ekosistem.

\begin{tabular}{clcc}
\hline No & \multicolumn{1}{c}{ Indikator } & Rata-Rata (\%) & Kriteria \\
\hline 1 & Isi Materi & 85 & Sangat baik \\
2 & Judul Rangkuman & 75 & Baik \\
3 & Soal Latihan & 75 & Baik \\
4 & Instrumen Penilaian & 75 & Baik \\
5 & Petunjuk Penggunaan bahasa dan istilah & 100 & Sangat baik \\
\hline Rata-rata & $\mathbf{7 7}$ & Sangat baik \\
\hline
\end{tabular}

Berdasarkan Tabel 2 rata-rata keseluruhan persentase kelayakan dari hasil penilaian para ahli materi didapatkan persentase total $77 \%$ sehingga dapat disimpulkan bahwa kelayakan penelitian ini berdasarkan komponen kelayakan dikategorikan "sangat baik". Selanjutnya uji coba pada siswa dengan skala besar bertujuan untuk mendapat respon siswa terhadap modul penelitian yang telah dikembangkan. Metode pengumpulan data yang dilakukan pada penelitian ini yakni dengan cara meminta para siswa untuk mengisi angket respon siswa. Angket respon siswa berisi dua kriteria diantaranya kesesuaian dengan tampilan dan kemanfaatan modul pembelajaran.

Tabel 3. Persentase Penilaian oleh Siswa

\begin{tabular}{ccc}
\hline Indikator & Rata-Rata (\%) & Kriteria \\
\hline $\begin{array}{c}\text { Mempermudah belajar dan } \\
\text { memahami materi }\end{array}$ & 81 & Sangat baik \\
$\begin{array}{c}\text { Meningkatkan motivasi dan } \\
\text { perhatian dalam KBM }\end{array}$ & 86 & Sangat baik \\
\hline Rata-rata & $\mathbf{8 6}$ & Sangat baik \\
\hline
\end{tabular}

Sumber : data diolah (2020)

Berdasarkan validasi ahli materi, tanggapan guru, dan siswa, maka dapat disimpulkan bahwa modul penelitian ini layak digunakan sebagai bahan ajar dalam pembelajaran Biologi kelas Xpada materi Ekositem.

\section{PEMBAHASAN}

Penelitian ini menggunakan model pengembangan 4-D (define, design, develop, dan disseminate). Pada tahap kegiatan pendefinisian (define) penelitian ini bertujuan untuk menetapkan dasar masalah dalam pengembangan modul pembelajaran, dan jalan keluar dari masalah tersebut melalui teori belajar yang relevan (Ibrahim et al., 2020). Berdasarkan hasil analisis pada tahap ini, maka ditemukan beberapa masalah dasar yang perlu mendapat perhatian dalam kegiatan pembelajaran yaitu: 1). motivasi dalam belajar biologi kurang karena model pendekatan pembelajaran yang dilakukan kurang variatif, 2). Pembelajaran selalu menggunakan buku paket dalam hal ini sangat kurang dalam mengeskplorasi materi dilingkungan sosial masyarakat, 3). Proses pembelajaran cendrungdilakukan dengan metode ceramah, saja tanpa menggunakan metode-metode lain seperti metode diskusi agar siswa lebih aktif dan giat dalam pembelajaran dan tanpa adanya kegiatan praktik di lapangan untuk menunjang pemahaman siswa. Oleh karena itu, dengan pemanfaaan modul penelitian dapat menjadi solusi untuk dapat meningkatkan kegiatan pembelajaran siswa lebih efektif lagi (Fitriani \& Indriaturrahmi, 2020).

Penelitian pengembangan/kelayakan bahan ajar dilakukan untuk meningkatkan pemahaman terhadap modul penelitian yang dikembangkan, maka pengembangan modul mengacu pada komptensi dasar pada materi ekositem sesuai dengan kurikulum 2013. Selain itu, pengembangan model ini juga dikembangkan dalam bentuk analisis tugas yang dijabarkan melalui lembar aktivitas peserta didik pada modul yang disediakan dan dapat dikerjakan secara individu atau berkelompok sehingga dapat meningkatkan pemahaman siswa terhadap modul yang dikembangkan. Disamping itu, pembelajaran bebasis penelitian ini sangat tepat diimplementasikan pada kurikulum 2013 karena telah terbukti meningkatkan kualitas dan hasil pembelajaran siswa.

Tahap kedua dalam pengembangan modul penelitian adalah tahap perancangan (design). Kegiatan utama dalam tahap kegiatan perancangan adalah penyusunan media pembelajaran untuk SMA Kelas X. Media pembelajaran tersebut meliputi, modul pembelajaran biologi materi ekosistem, rencana pelaksanaan 
pembelajaran diatur untuk 2 x pertemuan, lembar aktivitas peserta didik yang termuat dalam modul pembelajaran dan tes hasil belajar.

Tahap ketiga adalah pengembangan (development), pada tahap ini dilakukan evaluasi modul yang dikembangkan yaitu modul berbasis penelitian melalui validasi ahli.Salah satu kategori/kriteria yang paling utama dalam menentukan apakah sebuah perangkat pembelajaran dapat dipakai atau tidak adalah hasil dari validasi. Validasi ahli meliputi validasi modul dan materi yang dikembangkan, validasi respon guru terhadap modul dan validasi respon peserta didik terhadap modul (Ummah et al., 2017). Validasi ahli bertujuan untuk melihat aspek kelayakan modul pembelajaran sehingga modul tepat digunakan pada siswa. Proses validasi dilakukansebelum melaksanakan kegiatan pembelajaran di kelas hingga modul dan istrumen yang dikembangkan hingga mendapat kategori valid, selanjutnya dilakukan ujicoba di SMA Negeri 1 Wawonii Tengah di Kecamatan Wawonii Tengah Kabupaten Konawe Kepulauan.

Uji coba dilakukan dengan menggunakan modul dan perangkat yang telah divalidasi terlebih dahulu dan selanjutnya di uji cobakan oleh siswa telah diajarkan pada materi ekosistem.Uji coba ini bertujuan untuk melihat aspek kelayakan dan kegunaan modul yang dikembangkan sehingga layak untuk digunakan siswa dalam pembelajaran. Uji kelayakan dilakukan dalam 3 tahap. tahap pertama yaitu penilaian oleh ahli materi yang ditinjau dari aspek karakteristik modul dengan indikator terdiri dari isi materi, judul rangkuman, soal latihan, instrumen penilaian, referensi dan petunjuk penggunaaan bahasa dan istilah, dengan skor yang diperoleh sebesar 77\% dengan kategori kriteria sangat baik. Tahap kedua dilakukan oleh guru biologi yaitu diperoleh skor sebesar 72\% dan mendapat kategori kriteria baik. Tahap ketiga yaitu penilaian yang dilakukan oleh 24 siswa dalam skala besar, aspek yang dinilai yaitu tampilan modul dengan indokator terdiri dari bahasa, huruf dan gambar dan diperoleh skor $86 \%$ kategori kriteria sangat baik.Berdasarkan perhitungan tersebut modul berbasis riset dengan materi Ekosistem yang dikembangkan ini layak digunakan sebagai modul pembelajaran dengan nilai rata-rata kelayakan $86 \%$ dan masuk dalam kriteria "sangat baik". Menurut Balda (2021), penggunaan modul pembelajaran mudah digunakan dan dapat diaplikasikan oleh siswa didalam kelas. Khususnya pada materi biologi, pembelajaran membutuhkan bantuan media sebagai alat bantu yang menjadi kelengkapan dari fasilitas dengan kuantitas dan kualitas yang memadai (Balda, 2021). Selain itu, menurut Syarif Rizalia dalam penelitiannya menjelaskan bahwa penyusunan validasi dalam suatu alat pembelajaran sangat mempengaruhi kemampuan peserta didik dalam kegiatan pembelajarannya nanti sekaligus memudahkan peserta didik dalam memahami tuntutan materi yang ingin disampaikan. Oleh karena itu, setiap indikator penilaian kelayakan instrumen/modul perlu diperhatikan (Rizalia et al., 2021).

\section{KESIMPULAN}

Penelitian ini adalah penelitian pengembangan yang mengacu pada model 4-D Thiagarajan (define, design, develop, dan disseminate) yakni tahap pendefinisian, perancangan, pengembangan dan penyebaran. Analisis penelitian ini dilakukan pada tiga tahap yaitu tahap pendefinisian, perancangan dan pengembangan. Hasil dari penelitian ini menunjukan bahwa pengembangan modul/bahan ajar pada materi ekosistemyang telah dikembangkan dan telah digunakan disekolah SMA Negeri 1 Wawonii Tengah dalam proses pembelajaran dikatakan sangat layak digunakan dengan kategori sangat baikberdasarkan hasil validasi oleh parah ahli dengan skor $81 \%$ dan juga pada para siswa 86\%. Penggunaan modul materi ekosistem dapat menarik perhatian dan memotivasi siswa untuk lebih aktif dan giat dalam proses pembelajaran dan juga lebih mudah memahami materi sehingga dapat meningkatkan hasil belajar yang lebih baik.

\section{DAFTAR PUSTAKA}

Anafiyah, K., Sulistiyowati, E., \& Susilawati, L. (2015). Pengembangan Modul Ekosistem Berorientasi Kewirausahaan Untuk SMA/MA. XI(1), 72-77.

Balda, B. (2021). Perbandingan Hasil Belajar Siswa Menggunakan Pembelajaran Media Laboratorium dan Media Visual Pada Materi Sistem Eksresi di MAN 1 Konawe. KULIDAWA. https://doi.org/10.31332/kd.v1i2.1906

Fitriani, F., \& Indriaturrahmi, I. (2020). Pengembangan e-modul sebagai Sumber Belajar Mata Pelajaran Bahasa Indonesia Kelas X MAN 1 Lombok Tengah. Jurnal Penelitian Dan Pengkajian Ilmu Pendidikan: ESaintika. https://doi.org/10.36312/e-saintika.v4i1.165 
Ibrahim, I., Gunawan, G., \& Kosim, K. (2020). Validitas Perangkat Pembelajaran Fisika Berbasis Model Discovery dengan Pendekatan Konflik Kognitif. Jurnal Pijar Mipa. https://doi.org/10.29303/jpm.v15i3.1878

Lestari, A., Lianah, L., \& Hidayat, S. (2019). PENGEMBANGAN MODUL PEMBELAJARAN BIOLOGI BERBASIS KEARIFAN LOKAL DI KAWASAN WISATA GOA KREO PADA MATERI EKOSISTEM KELAS X SMA NEGERI 16 SEMARANG. Phenomenon: Jurnal Pendidikan MIPA. https://doi.org/10.21580/phen.2019.9.1.3113

Lorena, M., Kasrina, K., \& Yani, A. P. (2019). PENGEMBANGAN LKPD MODEL DISCOVERY LEARNING BERDASARKAN IDENTIFIKASI MANGROVE DI TWA PANTAI PANJANG BENGKULU. Diklabio: Jurnal Pendidikan Dan Pembelajaran Biologi. https://doi.org/10.33369/diklabio.3.1.59-66

Muqodas, R. Z., Sumardi, K., \& Berman, E. T. (2015). DESAIN DAN PEMBUATAN BAHAN AJAR BERDASARKAN PENDEKATAN SAINTIFIK PADA MATA PELAJARAN SISTEM DAN INSTALASI REFRIGERASI. Journal of Mechanical Engineering Education. https://doi.org/10.17509/jmee.v2i1.1160

Nurrita, T. (2018). Pengembangan Media Pembelajaran Untuk Meningkatkan Hasil Belajar Siswa. MISYKAT: Jurnal Ilmu-Ilmu Al-Quran, Hadist, Syari'ah Dan Tarbiyah, 3(1), 171-187. https://doi.org/10.33511/misykat.v3n1.171

Rakhmatullah, R., Rapi, M., \& Zulkarnaim, Z. (2020). PENGEMBANGAN MODUL PEMBELAJARAN BIOLOGI MATERI SISTEM REPRODUKSI TERINTEGRASI KEILMUAN ISLAM UNTUK SISWA KELAS XI MADRASAH ALIYAH. Jurnal Biotek. https://doi.org/10.24252/jb.v8i1.9287

Rizalia, S., Syam, A. N., \& Yulita, N. (2021). Kajian Kualitatif Tes Hasil Belajar Buatan Guru Biologi MAN di Kota Kendari. Journal of Natural Science and Integration. https://doi.org/10.24014/jnsi.v4i1.10410

Setiawan, Y. E., \& Mustangin, M. (2020). Validitas Model Pembelajar IDEA (Issue, Discussion, Establish, and Apply) untuk Meningkatkan Pemahaman Konsep. JP3M (Jurnal Penelitian Pendidikan Dan Pengajaran Matematika). https://doi.org/10.37058/jp3m.v6i1.1432

Suharsimi, A. (2006). Prosedur penelitian suatu pendekatan praktik. Jakarta: Rineka Cipta.

Ummah, R., Suarsini, E., \& Lestari, S. R. (2017). Analisis Kebutuhan Pengembangan E-Modul Berbasis Penelitian Uji Antimikroba pada Mata Kuliah Mikrobiologi. Seminar Pendidikan IPA.

Wahyuni, N., \& Lufri, L. (2021). Science Module Development Based on Scientific Approach for Life Organization Subject in Junior High School. Jurnal Atrium Pendidikan Biologi, 6(1), $20-27$. http://ejournal.unp.ac.id/students/index.php/pbio/article/download/10697/4497 